\title{
Technology Adoption by Farmers for the Sustainability of Agriculture Sector
}

\author{
P.Uma Rani, Padmalosani
}

\begin{abstract}
Agriculturalists are the principal managers who can shape the surface of the Earth in the coming years. In India government has been implementing new schemes for ensuring the sustainability of agriculture so as to meet the demands of improving yields and for the sustainability of agriculture sector. Indian Government has taken lot of initiatives to transform agriculture sector though e marketing of agriculture produce. 58 per cent of population depend upon agriculture for their livelihood. Agriculture sector is a highly dangerous sector that is facing ups and downs during the crop production stage. Agriculturists suffer from marketing their produce. The farmer's income is not stable due to the fall in their crop yield and the selling price of their produce. Government is concerned with helping farmers to increase their yield and have framed policies to form a competitive market structure which will indirectly help to enhance the marketing efficiency of farmers. Our government has taken initiative to combine the market to improve the marketing efficiency of agriculturist.
\end{abstract}

Key words: Agriculture sector, agriculture marketing, integrated market

\section{INTRODUCTION}

India holds 157.35 million hectares agricultural land and stands one of the largest in the universe. Our farmers produce more of spices, oilseeds, pulses, tea, cashew, sugarcane and jute since it is more suitable for our climate. In north India agriculturist produce more of wheat, rice, fruits and vegetables and cotton. In India we produce more of mango, grapes and banana as it is suitable for our land. Government has taken a decision to frame a new Act to market agriculture produce. Present government has carved path of success for agriculture sector.

In 1950 yield of agriculture sector was high that in turn helped to increase the GDP of our nation, when compared to the present produce. Currently our government concentrates more on industrial sector rather than agriculture. Though majority of our population depended on agriculture their return continued to be low. Maintenance cost and capital investments are high but the rate of return on investments was low. Produce is very less due to soil erosion and the farmers hold small portion of land. Since agriculture is losing its return, government has decided to pool more land for irrigation, and offer electricity to all villages. Government has planned a new pattern through transparent schemes. Government of India has distributed soil health cards, expansion of irrigation facilities, organic farming, national

Revised Version Manuscript Received on August 19, 2019.

Dr.P.Uma Rani, Professor \& Head-DoMS. Saveetha Engineering College, Chennai, Tamil Nadu, India.(Email: : umarani@ saveetha.ac.in)

Ms.Padmalosani, Faculty,Accounting\& Finance - Business studies, Ibra College of Technology, Ibra, Al-Sharqiyah Region, Sultanate of Oman.(Email: : d.padmalosani@gmail.com) agriculture market, bee keeping, and agricultural education for the growth of agriculture sector.

\section{REVIEW OF LITERATURE}

Dr. G.L.Parvathamma in her paper Farmers suicide and response of Government of India (2016) has explained various reasons for farmers committing suicide. Government of India has launched rehabilitation package to mitigate distress of farmers through supply of institutional credit, debt relief and subsidiary income through fisheries and dairying.

NikithaSattiraju in her article "Could the National Agricultural Market be an answer to farmer woes?" (2016) has stated that as per APMC Act agriculturist need to sell their produce only in the government authorised markets. Since such markets are not available in all places, many times farmers sell their produce to local traders and moneylenders, finally farmers do not receive the expected returns. As per APMC rules they do not have direct contact with agriculturist, which help middlemen to take advantage of the small and poor farmers.

AsishSinha in his article "Decoding NAM" (2016) explained that as per current law each market must obtain separate license and also the government restrict free movement of agricultural products from one state to other. Though the government has taken initiative to interconnect all the markets through online and help farmers the above restrictions of NAM only harm the farmers.

KushankurDey in his article "Rationale, Roll-out and Ramifications of NAM" (2016) specified that the aim of NAM is to create technology oriented environment that will help to integrate the agriculture markets within our nation. He suggested that to improvise the agriculture market structure, there must be stable market agents who will spread the real time price information.

RajalakshmiNirmal in her article "E NAM - A long way to go" (2016) expressed that this idea is good but it is still at emerging stage. Government has to take steps to make this scheme more attractive to agriculturists, so that they really get benefited out of this initiative. The nature of NAM allows the members to act independently, which must be restricted.

Mekhala Krishnamurthy in her article "What is in NAM" (2016) has critically analysed the challenges faced by NAM. She has mentioned 2 reforms required for the success of NAM that includes single license to be given in all markets and they must levy single point market fee. If these legislative actions are taken by the government this initiative will be a boon to farmers. 
SudhakarGummula and AnkushAgrawal in their article "Is the National agriculture Market platform a game changer?" (2016) specified about FCI and NAM combination - A win win situation. The budget offered the setting up of an online buying system by FCI, though it is not mentioned whether it will be through NAM platform. FCI is investigating NAM way for procuring produce and it will create a win-win situation since large quantities procured by FCI could utilize the NAM platform a feasible system, while FCI benefits from its electronic transaction processing activities.

Harish Damodaran in his article "What is in NAM" (2014) tried to analyse if this initiative will make a difference in farmers marketing of their produce? He found that the agriculturists are restricted to sell their produce only to few licensed traders. If the farmers to be promoted and get rid off the local traders and moneylenders agriculture co operative societies can help them through gathering together as a cluster that will help for the success of virtual marketing.

MahendraDev in his paper Small farmer's challenges and opportunities (2014) has mentioned that 98 million farmers hold small margin of land whose income is less than marginal consumption, hence they borrow to meet out their needs.

\section{OBJECTIVES}

- To study the problems of farmers in marketing their produce

- To analyse the importance of technology to sell produce through NAM

- To offer suggestions to market produce through NAM

\section{RESEARCH METHODLOGY}

Descriptive research design followed.

Primary data collected from 200 farmers around Chennai. Questionnaire was framed and data collected through this instrument. Secondary data collected through newspapers, websites and journals. Convenient sampling method used to collect data.

\section{Chart -1}

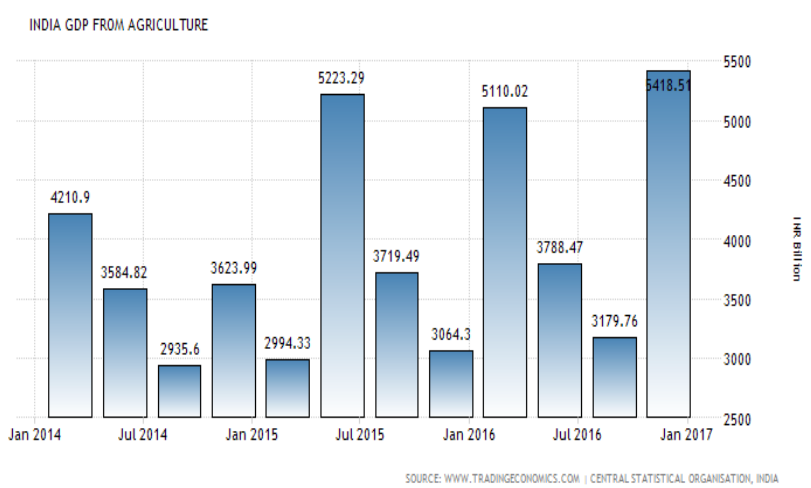

Source: Central statistical organisation

\section{MARKETING PROBLEMS FACED BY FARMERS}

The above chart shows that GDP from agriculture sector is in increasing trend. Farmers are in unrest after a abundant crop due to fall in prices which is terrible for farmers. The government has formed Food Corporation of India to ease farmers. Some solution must be found for agriculturist else they will move from villages to cities. Since there is abundant production in food there is no necessity to import from other countries. The use of chemical fertilizer and pesticides has affected our soil and water. More than 3 lakh farmers committed suicide due to the rise in cost of cultivation. Investment in agro processing infrastructure will help farmers to move up in value chain that will help farmers to get their due share for their products. There must be coordination among farmers' to enable them to benefit in marketing their produce. Government has come forward with a wide spread policy of National Agriculture Market to assist farmers.

The various market of agriculture produce is channelized through Agriculture Produce Market Committee (APMC). Agriculturist suffers due to numerous charges of market fees, heavy market rates in different APMCs. There is poor use of technology, information irregularity, and lack of transparency in pricing, higher market charges, lack of control that affects agriculture sector. It has become the need of the day that the markets at all level has to be combined, so that the farmers will get better price, improve logistics services to decrease wastages and form a national market. Agricultural Produce Market Committee was formed to assist farmers to sell their produce at lucrative price.

\section{NATIONAL AGRICULTURE MARKET WORKING MODEL (NAM)}

This programme was launched to connect mandis in our country, under which 20 states have joined under this scheme. E marketing initiated in 2016, and 200 markets joined immediately. NAM helps farmers to sell their produce in the markets where there is a demand instead of local market. Secondly, agricultural produce processing facility must be available where the produce is produced in huge quantity so that they can fetch good price based on the demand/ supply gap. In India many farmers own small land; hence they do not take their crop to the mandis. They sell their produce to the local middlemen, though there is possibility for selling at better price through online.

Government of India has taken many initiative schemes like PradhanMantriKrishiSinchayeeYojana (to increase productivity), ParamparagatKrishiVikasYoaja (organic farming), Soil Health Card Scheme(test soil), PradhanMantriFasalBimaYojna (insurance coverage to farmers), My Village My Pride (ICAR adopt villages and promote best farming practices), Achievements of National Rice Research Institute, Cuttack Achievements of National Rice Research Institute, Cuttack and National Agriculture Market (e-NAM).The Department of Agriculture \& Cooperation is concerned about increasing the net returns of the agriculturist. With this intention they created a unified market, which is integrated across the nation. After 2014 and 2015 budgets an "Agri-Tech Infrastructure Fund" and 'National Agriculture Market' was set up.

Government has allotted Rs 200 crores in this budget to start NAM which will assist in meeting installation of 
software expenses, setting up soil testing laboratories. States that will join under this scheme will eliminate multiple license, reduce fees and make arrangements for e auction. NAM integrates and regulates 585 Agricultural Produce Marketing Committees (APMC)

\section{FACTORS AFFECTING NAM\& RESULTS}

- Techno infrastructure relates to selling their produce directly using electronic auction system

- To avoid monopoly, famers can deal with different buyers for their produce to get better price.

- Quality check prevents defective products from reaching the customers

- Grading relates to sorting agriculture products based on size, shape and quality

- Quality warehouse helps to hold and preserve goods from the time they are produced till consumption

Chart- 2

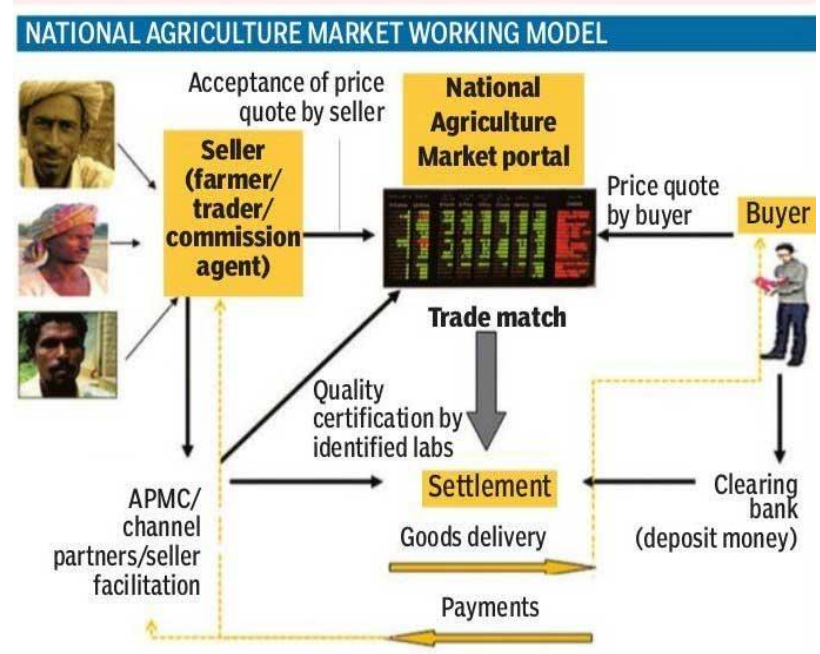

Source: Small Farmers' Agribusiness Consortium (SFAC)

Source: SFAC

APMC laws permit first sale of crops only in regulated market yards or mandis. National Agriculture Market (NAM) was formed to help farmers. Traders have to procure license to operate in different mandis within the same state. NAM is online trading platform that helps farmers to sell their produce to buyers anywhere in the country. The buyers need not physically present to trade with farmers. They can log on to the e platform and source from any mandi in India. The APMC insist the farmers to sell their produce to intermediary authorised by the government.

NAM help famers to sell produce at nominal price through good networking with many buyers throughout our nation. The Central Government has realized the active participation of the State Governments for successful implementation of the scheme. The Government has made 'National Agricultural Market' a reality. It is definitely a boon to farmers and the agricultural sector, by creating greater wealth at macro level and higher income at farmer's level.

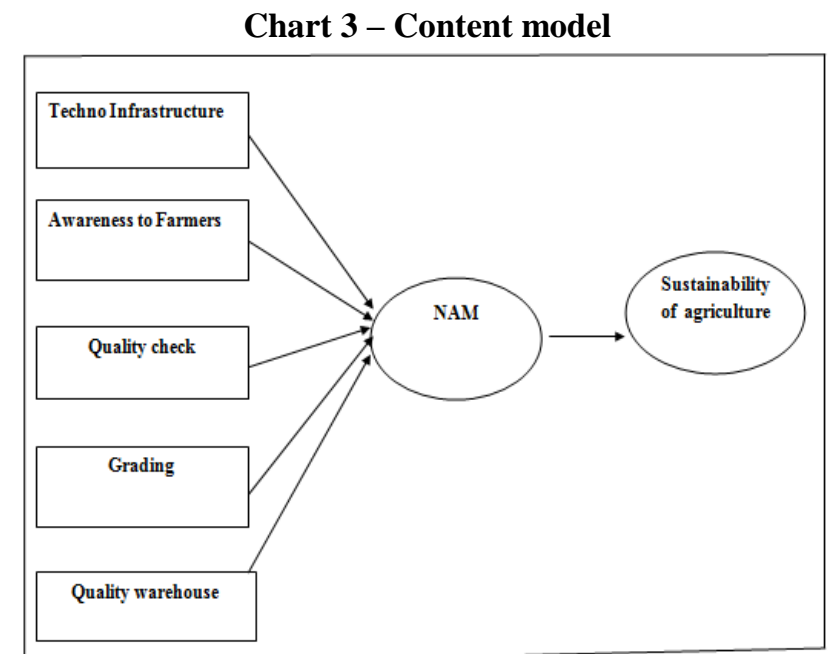

Multiple Regression Analysis used to find out customer satisfaction from National Agricultural Market. In this analysis, the dependent variable is Sustainability of Agriculture and the Independent variables are Techno Infrastructure, Awareness to farmers, Quality Check, Grading and Quality Warehouse. This analysis helped in predicting

\section{SUSTAINABILITY OF AGRICULTURE}

Table -1 Descriptive Statistics

\begin{tabular}{|l|c|c|c|}
\hline & Mean & SD & N \\
\hline SUSTAINABILITY OF AGRICULTURE & 18.95 & 2.236 & 200 \\
\hline Techno Infrastructure & 11.78 & 1.331 & 200 \\
\hline Awareness to farmers & 9.82 & 1.555 & 200 \\
\hline Quality Check & 11.39 & 1.597 & 200 \\
\hline Grading & 11.44 & 1.533 & 200 \\
\hline Quality Warehouse & 12.47 & 1.566 & 200 \\
\hline
\end{tabular}

Table - 2 Regression Analysis

\begin{tabular}{|c|c|c|c|c|c|}
\hline \multirow[t]{2}{*}{ Model } & \multicolumn{2}{|c|}{$\begin{array}{l}\text { Unstandardized } \\
\text { Coefficients }\end{array}$} & \multirow{2}{*}{$\begin{array}{c}\text { Standardized } \\
\text { Coefficients }\end{array}$} & \multirow[t]{2}{*}{$t$} & \multirow[t]{2}{*}{ Sig. } \\
\hline & B & Std. Error & & & \\
\hline (Constant) & 6.862 & 1.341 & & 5.117 & .000 \\
\hline TechnoInfrastructure & .123 & .027 & .128 & 4.605 & .000 \\
\hline Awareness to farmers & -.152 & .034 & -106 & -4.537 & .000 \\
\hline Quality Check & .095 & .034 & .164 & 5.814 & .000 \\
\hline Grading & .590 & .052 & .255 & 11.412 & .000 \\
\hline Quality Warehouse & .773 & .036 & .542 & 22.051 & .000 \\
\hline
\end{tabular}

Regression is the determination of statistical relationship between two or more variables. In this analysis, the dependent variable is SUSTAINABILITY OF AGRICULTURE and the Independent variables are Techno Infrastructure,

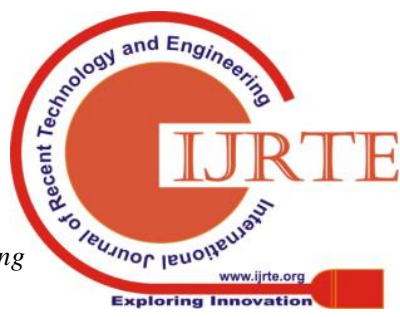


awareness of farmers, quality check, grading and ualitywarehouse.This combination of Five in dependent variables predicts the dependent variable, Farmer

Satisfaction, $\mathrm{F}(5,194)=71.456$, Adjusted $\mathrm{R}^{2}=0.769, p=$ .000 which is lesser than .001 (Sig. Value 2- tailed). For predicting Sustainability of Agriculture, Quality Warehouse (0.542) is the strongest influencing factors. The beta weights suggest that Quality Warehouse only contribute most $(0.542$ or $54 \%)$ to predict Sustainability of Agriculture.

Quality Warehouse may have a standardized regression coefficient of 0.540 . It means for every one Standard Deviation of increase in the Quality Warehouse, scores on Sustainability of Agriculture increase by 0.540 Standard Deviations, controlling for the scores of other variables in the equation. From the unstandardized coefficient, it is found that the one-unit increase in the Quality Warehouse would increase the Sustainability of Agriculture by 0.773 units.

Techno Infrastructure (0.128), Quality Check (0.164) and Grading (0.255) also predict the Farmer Satisfaction significantly but lesser than Quality Warehouse. However, Awareness to Farmers (-0.106) inversely influences the Sustainability of Agriculture since the value is negative and it is significant. The adjusted $R$ squared value was 0.769 . This indicates that $77 \%$ of the variance in the Sustainability of Agriculture can be predicted from the independent variables. Remaining $33 \%$ is unexplained. According to Cohen (1988), this is large effect.

\section{LACK OF INFRASTRUCTURE FOR NAM}

Our government is planning one nation one market to enhance agricultural sector under NAM, but there is lack of awareness among farmers that this scheme through which they can sell their produce beyond their region at best price. There is lack of infrastructure to sell their produce through NAM. $80 \%$ of mandis do not have quality checking, grading, assaying and warehousing set up to market their produce. As farmers will be selling their produce through NAM to other distant states it will take some time to deliver their produce for which quality warehouse is required, which is lacking in many states in our country. NAM techno infrastructure platform must be set to make use of NAM. Liberal credit must be offered to agriculturist to save them from the clutches of the moneylenders. This will encourage small farmers to access NAM to sell their produce. There must be uniform standards for quality, grading and processing which will result in standard product that can be offered for sale through NAM. As Indian farmers have small land holdings; lack of water for irrigation, inadequate credit, we have to wait and see how NAM will play to change the life style of farmers.

\section{FINDINGS}

- Farmers sell only 10 per cent of their produce through National Agricultural Market(NAM)

- Though there are many market committees only 10 percent of them are connected to NAM says the government report
- Farmers from one region sell their goods to other region due to better price.

- Very few commodities have similar standards. Based on climate, quality of some produce varies in different places.

- NAM is concerned with only standardized agricultural produce that was stated in the government report

- The RBI report stated that 130 markets were started

- Each state is permitted to link with the national exchange.

- The mismatch between demand and supply will be reduced

- Farmers linked to NAM are paid through online.

- Banks finance farmers who wish to store their produce and sell later.

- It was reported by the government that 21 mandi's from 8 states joined NAM (Haryana, UP, HP, MP, Gujarat, Telengana, Jharkhand and Rajasthan)

- It was found through mandi that NAM is trading with only few crops

\section{SUGGESTIONS}

- As Fruits and vegetables are subject to price fluctuations and perishable; they must be allowed to sell through NAM platform.

- Azadpur and Vashi have big markets, it will be good if they join NAM

- There must be a clear directions regarding payment of charges and taxes.

- All the states in India have to be incorporated under e-NAM, to ensure a single license for trading

\section{CONCLUSION}

Though NAM is an online market it has a physical market that can be accessed online. NAM is concerned with fragmented markets, reducing brokerage expenses and offering nominal prices to the consumer. The physical market enables the farmers to sell their yield within our country. Special software developed for NAM that helps to widen the network and satisfy the needs of customers. Single trading license can be used to trade in all mandi. The farmers can choose either local offer or online offer. The maintenance cost of NAM will be borne by Ministry of Agriculture and Farmers welfare.

The ongoing farmer's agitation has taken a shocking violent form. Though farmers got bumper crop, prices have fallen which is good for consumers and terrific for farmers. In spite of the government taking steps to safeguard farmers, farmers are still under financial crunch. Let us assume there are two people cultivating paddy in Tanjore district of Tamil Nadu. The farmer who has good knowledge about market will sell his yield in Kerala at a higher price due to the high demand rather than selling produce in Tamil Nadu where there is abundant yield. As the other farmer was not aware of market conditions in Kerala he will sell his produce at less price in local market. But now with the help of e marketing the farmers are aware of prices in different states in our nation. Indian agriculture is

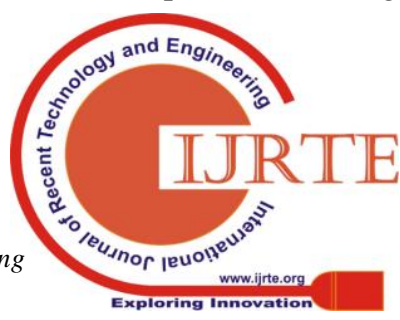


going through a dynamic phase and the government of India is focusing towards creating next leg of green revolution and gives our farmers motivation to remain in this sector and feed our population.

\section{REFERENCE}

1. Business Standard

2. Business Line

3. The Indian Express

4. The Hindu

5. www.department of Agriculture \& Cooperation, Ministry of Agriculture.

6. https://en.wikipedia.org/wiki/NAM

7. www.enam.gov.in/

8. www.ibef.org 